\title{
Effect of Boron Levels and Farmyard Manure on Physiological Growth and Quality of Sesame (Sesamum indicum)
}

\author{
K. Mamatha ${ }^{1 *}$, G.E.Ch. Vidyasagar ${ }^{1}$, P. Laxminarayana ${ }^{1}$ and G. Padmaja ${ }^{2}$ \\ ${ }^{1}$ Department of Agronomy, ${ }^{2}$ Department of Soil Science and Agricultural Chemistry, College of \\ Agriculture Professor Jayashankar Telangana State Agricultural University Rajendranagar, \\ Hyderabad 500030 Telangana, India \\ *Corresponding author
}

\section{A B S T R A C T}

\section{Keywords}

Sesame, Farmyard manure, Boron, Physiological growth and Quality.

Article Info

Accepted:

21 June 2017

Available Online:

10 August 2017
The experiment was conducted on Effect of Boron levels and farmyard manure on physiological growth and quality of sesame (Sesamum indicum) at college farm college of agriculture, Rajendranagar during kharif season 2014 in split-plot design with two main treatments viz $\mathrm{M}_{1}$ (recommended dose of fertilizers (RDF), 40-60-40 kg NPK ha ${ }^{-1}$ ) and $\mathrm{M}_{2}$ (RDF) along with application of 25 per cent $\mathrm{N}$ through farmyard manure and three subtreatments viz $S_{1}\left(2.5 \mathrm{~kg} \mathrm{~B} \mathrm{ha}^{-1}\right), \mathrm{S}_{2}\left(5.0 \mathrm{~kg} \mathrm{~B} \mathrm{ha}^{-1}\right)$ and $\mathrm{S}_{3}\left(7.5 \mathrm{~kg} \mathrm{~B} \mathrm{ha}{ }^{-1}\right)$. Application of RDF along with 25 per cent $\mathrm{N}$ through FYM recorded higher leaf area index, crop growth rate, relative growth rate, seed yield and quality of sesame over application of RDF alone. Among boron levels application of $7.5 \mathrm{~kg}$ boron $\mathrm{ha}^{-1}$ recorded leaf area index, crop growth rate, relative growth rate, seed yield and quality of sesame and it was on par with application of over application of $5.0 \mathrm{~kg} \mathrm{ha}^{-1}$.

\section{Introduction}

Sesame, Sesamum indicum L (Pedaliaceae) is one of the most important oilseed crops extensively grown in different parts of the world and it ranks fourth among oilseed crops in the world.

Sesame is drought resistant crop which can easily be grown under rainfed conditions; has been grown all over the world for thousands of years and is said to be ancient crop in India. It can play an important role to fulfil the local demand of edible oil. Since it is short duration and photo-insensitive crop with wider adaptability, it can be cultivated throughout the year.

Prolonged use of chemical fertilizers alone in intensive cropping systems leads to unfavourable soil fertility, harmful effects on soil physico-chemical and biological properties and undermine sustainable crop production. Deficit of organic matter makes the situation worst for oilseed crops. Among the micronutrient deficiencies, boron deficiency is the second most dominant problem globally (Alloway, 2008). 
The importance of boron deficiency has been reported by Chatterji and Nautiyal (2000). Among the micronutrients boron deficiency is one of the widest spread micronutrient deficiency in India. Boron is involved in pollen germination. Its deficiency and toxicity cause lower chlorophyll content and rate of photosynthesis and may induce cell wall synthesis influencing the activity of the plasma lemma and can disturb the maintenance of meristem in the plants.

Higher level of boron reduced seed yield and oil content (Bolanos et al., 2004). It has been reported that boron is required for pollen germination and pollen tube growth (Dugger 1983). Boron deficiency can affect pollen viability and abortion of stamen and pistils which contribute to low seed set as reported by Chatterjee and Nautiyal (2000).

\section{Materials and Methods}

The present experiment on sesame was conducted during Kharif 2014 at college farm, College of Agriculture, Rajendranagar, Professor Jayashankar Telangana State Agricultural University, Rajendranagar, Hyderabad. The farm is geographically situated at an altitude of $542.6 \mathrm{~m}$ above mean sea level on $17^{\circ} 19^{\prime} \mathrm{N}$ latitude and $78^{\circ} 28^{\prime} \mathrm{E}$ longitude. It is in the southern Telangana agro-climatic zone of the state.

Hima (JCS 9426) suitable for Kharif, Rabi and summer conditions matures in 90 days with yield potential of $750 \mathrm{~kg} \mathrm{ha}^{-1}$. It is a short duration white seeded variety with long capsules. The soil of the experimental site was sandy loam in texture with $\mathrm{pH}$ of 7.9 and electrical conductivity $0.41 \mathrm{dS} \mathrm{m} \mathrm{m}^{-1}$, low in organic carbon $(0.40 \%)$ and available nitrogen $\left(175 \mathrm{~kg} \mathrm{ha}^{-1}\right)$, medium in available phosphorus (36 kg ha ${ }^{-1}$ ), high in available potassium $\left(342 \mathrm{~kg} \mathrm{ha}^{-1}\right)$.
The experiment was laid out side by side in a split-plot design with 6 treatments comprising two main plot treatments viz. $\mathrm{M}_{1}$ (recommended dose of fertilizers (RDF) and $\mathrm{M}_{2} \quad(\mathrm{RDF}$ along with $25 \% \quad \mathrm{~N})$ through farmyard manure with three sub-plot treatments in each experiment viz. three boron levels viz. $\mathrm{S}_{1}\left(2.5 \mathrm{~kg} \mathrm{~B} \mathrm{ha}{ }^{-1}\right), \mathrm{S}_{2}\left(5.0 \mathrm{~kg} \mathrm{~B} \mathrm{ha}^{-1}\right)$ and $S_{3}\left(7.5 \mathrm{~kg} \mathrm{~B} \mathrm{ha}^{-1}\right)$ replicated four times. Full dose of $\mathrm{P}_{2} \mathrm{O}_{5}$ and $\mathrm{K}_{2} \mathrm{O}$ along with half of the nitrogen in all the treatments was applied as basal. Remaining nitrogen was applied 30 DAS.

\section{Results and Discussion}

\section{Physiological growth parameters}

\section{Leaf area index}

Leaf area index of sesame was significantly influenced by main treatments and sub treatments. As the crop growth period increased from 15 to 45 DAS the leaf area index was also increased gradually and later decreased. Leaf area index at 45 DAS was found to be maximum (2.38) under $\mathrm{M}_{2}$ i.e. application of RDF along with $25 \% \mathrm{~N}$ through FYM when compared to application of RDF alone (2.06). Within the sub-plot treatments there was significant difference observed in leaf area index of sesame at all crop growth stages except at harvest. The highest leaf area index (2.50) was obtained in $\mathrm{S}_{3}$ treatment i.e. $7.5 \mathrm{~kg} \mathrm{~B} \mathrm{ha}^{-1}$ and it was on par with $\mathrm{S}_{2}$ i.e. $5.0 \mathrm{~kg} \mathrm{~B} \mathrm{ha}{ }^{-1}$ (2.41). The lowest leaf area was observed in $\mathrm{S}_{1}$ i.e. $2.5 \mathrm{~kg}$ $\mathrm{B} \mathrm{ha}^{-1}(1.75)$ at 45 DAS.

\section{Crop growth rate}

The results of crop growth rate of sesame were significantly influenced by main treatments i.e. RDF along with $25 \% \mathrm{~N}$ through FYM and RDF alone. The crop 
growth rate of sesame was found to be maximum at 45-60 DAS and decreased thereafter. The crop growth rate of sesame crop was significantly more under RDF along with $25 \% \mathrm{~N}$ through FYM $\left(9.00 \mathrm{~g} \mathrm{~m}^{-2}\right.$ day $\left.^{-1}\right)$ as compared to RDF alone (7.35 $\mathrm{g} \mathrm{m}^{-2}$ day $\left.^{-1}\right)$ at 45-60DAS.

Among the sub treatments there was significant difference for crop growth rate of sesame. The $S_{3}$ i.e. application of $7.5 \mathrm{~kg} \mathrm{~B} \mathrm{ha}^{-1}$ at 45-60 DAS had recorded highest crop growth rate $\left(8.51 \mathrm{~g} \mathrm{~m}^{-2} \mathrm{day}^{-1}\right)$ and it is on par with $\mathrm{S}_{2}$ i.e. application of $5.0 \mathrm{~kg} \mathrm{~B} \mathrm{ha}^{-1}(8.48 \mathrm{~g}$ $\mathrm{m}^{-2}$ day $\left.^{-1}\right)$. The lowest crop growth rate was recorded with $\mathrm{S}_{1}$ i.e. application of $2.5 \mathrm{~kg} \mathrm{~B}$ $\mathrm{ha}^{-1}\left(7.52 \mathrm{~g} \mathrm{~m}^{-2}\right.$ day $\left.^{-1}\right)$.

\section{Relative growth rate}

The results of relative growth rate of sesame were significantly influenced by main treatments i.e. RDF along with $25 \% \mathrm{~N}$ through FYM and RDF. The relative growth rate of sesame crop was significantly more under RDF along with $25 \% \mathrm{~N}$ through FYM $\left(0.071 \mathrm{~g} \mathrm{~g}^{-1} \mathrm{day}^{-1}\right)$ as compared to RDF alone (0.059 $\left.\mathrm{g} \mathrm{g}^{-1} \mathrm{day}^{-1}\right)$ at 45-60 DAS.

Among the sub treatments there was significant difference for relative growth rate $\left(\mathrm{g} \mathrm{g}^{-1} \mathrm{day}^{-1}\right)$ of sesame. The $\mathrm{S}_{3}$ i.e. application of $7.5 \mathrm{~kg} \mathrm{~B} \mathrm{ha}^{-1}$ had recorded highest crop growth rate $\left(0.063 \mathrm{~g} \mathrm{~g}^{-1}\right.$ day $\left.^{-1}\right)$ and it was on par with $\mathrm{S}_{2}$ i.e. application of $5.0 \mathrm{~kg} \mathrm{~B} \mathrm{ha}$ $\left(0.062 \mathrm{~g} \mathrm{~g}^{-1} \mathrm{day}^{-1}\right)$. The lowest relative growth rate $\left(0.059 \mathrm{~g} \mathrm{~g}^{-1} \mathrm{day}^{-1}\right)$ is recorded with $\mathrm{S}_{1}$ i.e. application of $2.5 \mathrm{~kg} \mathrm{~B} \mathrm{ha}^{-1}$ at harvest.

Rapid increase in the leaf area index, crop growth rate and relative growth rate of sesame under RDF and 25\% N through FYM from 30 to harvest might be due to beneficial effect of combined use of fertilizers and FYM. Similar findings were reported by Tripathy and Bastia (2012). Application of boron @ $7.5 \mathrm{~kg} \mathrm{~B} \mathrm{ha}^{-1}$ might have increased the leaf area index, crop growth rate and relative growth rate due to escalated the chlorophyll content of leaves increased the photosynthetic activity and new tissue growth. Similar findings were reported by Jeena et al., (2013).

\section{Yield}

Data on yield viz. seed yield $\left(\mathrm{kg} \mathrm{ha}^{-1}\right)$, stover yield $\left(\mathrm{kg} \mathrm{ha}^{-1}\right)$ and harvest index (\%) of sesame crop as influenced by application of boron with or without use of farmyard manure are presented in table 1.

\section{Seed yield $\left(\mathrm{kg} \mathrm{ha}^{-1}\right)$}

Seed yield was significantly influenced by main treatments i.e. application of RDF along with 25 per cent $\mathrm{N}$ through FYM. Seed yield was significantly higher $\left(540 \mathrm{~kg} \mathrm{ha}^{-1}\right)$ when the crop was fertilized with RDF along with 25 per cent $\mathrm{N}$ through $\mathrm{FYM}$ over application of RDF alone (461 kg ha ${ }^{-1}$ ). Higher seed yield of sesame was obtained with RDF along with 25 per cent $\mathrm{N}$ through FYM which may be due to more availability of nutrients and their uptake. Similar findings were also reported by Saeed et al., (2002) who stated that organic manure alone or in combination with synthetic fertilizers significantly increases grain and biological yield. Within the subplots the seed yield was significantly higher $\left(521 \mathrm{~kg} \mathrm{ha}^{-1}\right.$ ) in $\mathrm{S}_{3}$ Influence of boron on sesame $\left(7.5 \mathrm{~kg} \mathrm{~B} \mathrm{ha}^{-1}\right)$ and it was on par with $\mathrm{S}_{2}\left(5.0 \mathrm{~kg} \mathrm{~B} \mathrm{ha}^{-1}\right)\left(513 \mathrm{~kg} \mathrm{ha}^{-1}\right)$. The seed yield with $2.5 \mathrm{~kg} B \mathrm{ha}^{-1}$ was found significantly lower $\left(350 \mathrm{~kg} \mathrm{ha}^{-1}\right)$ compared to rest of the treatments. Application of boron $7.5 \mathrm{~kg} \mathrm{ha}^{-1}$ owing to availability of more nutrients for higher yield attributes (capsules plant $^{-1}$, seeds capsule ${ }^{-1}$ and test weight) proved best. These results are in line with those of Oyinlola (2007) and Patil et al., (2006). Interaction effect of seed yield of sesame crop influenced by main and sub treatments were found to be non-significant. 
Stover yield (kg ha $\left.{ }^{-1}\right)$

Stover yield was significantly influenced by RDF along with 25 per cent $\mathrm{N}$ through FYM. Stover yield was significantly higher $(1087 \mathrm{~kg}$ $\mathrm{ha}^{-1}$ ) when the crop was fertilized with RDF along with 25 per cent $\mathrm{N}$ through FYM in comparison to sole application of RDF (938 $\mathrm{kg} \mathrm{ha}^{-1}$ ) at harvest.

The increase in crop dry matter with organic sources might be attributed to considerable increase in plant height, number of branches and effective utilization of nutrients, moisture and light.

These results tend to support the results of Barik and Fulmali (2011).
Within the sub-plots the stover yield of 1083 $\mathrm{kg} \mathrm{ha}^{-1}$ was significantly higher than $\mathrm{S}_{3}(7.5$ $\left.\mathrm{kg} \mathrm{B} \mathrm{ha}{ }^{-1}\right)$ which was on par with $S_{2}(5.0 \mathrm{~kg} \mathrm{~B}$ $\left.\mathrm{ha}^{-1}\right)\left(1008 \mathrm{~kg} \mathrm{ha}^{-1}\right)$. The stover yield with 2.5 $\mathrm{kg} \mathrm{B} \mathrm{ha}{ }^{-1}$ was found to be lower (904 kg ha-1). Gitte et al., (2005) reported that application of boron $7.5 \mathrm{~kg} \mathrm{ha}^{-1}$ owing to availability of more nutrients for plant growth parameters like plant height, branches plant ${ }^{-1}$ and leaf area index and ultimately dry matter plant $^{-1}$ increased the biological yield which might be due to role of boron in cell elongation, cell division and biomass accumulation. Interaction effect of stover yield influenced by main and sub-treatments was found to be non-significant.

Table.1 Leaf area index, crop growth rate and relative growth rate as influenced by boron levels and farmyard manure application

\begin{tabular}{|c|c|c|c|}
\hline Treatments & $\begin{array}{c}\text { Leaf Area } \\
\text { Index }\end{array}$ & $\begin{array}{c}\text { Crop growth rate } \\
\left(\mathrm{g} \mathrm{m}^{-2} \mathrm{day}^{-1}\right)\end{array}$ & $\begin{array}{c}\text { Relative growth rate (g } \\
\left.\mathrm{g}^{-1} \mathrm{day}^{-1}\right)\end{array}$ \\
\hline \multicolumn{4}{|l|}{ Main treatments } \\
\hline $\mathrm{M}_{1}: \mathrm{RDF}$ & 2.06 & 7.35 & 0.059 \\
\hline $\begin{array}{l}\mathrm{M}_{2}: \mathrm{RDF}+25 \% \mathrm{~N} \text { through } \\
\mathrm{FYM}\end{array}$ & 2.38 & 9.00 & 0.071 \\
\hline SEm \pm & 0.01 & 0.06 & 0.002 \\
\hline $\mathrm{CD}(\mathrm{P}=0.05)$ & 0.03 & 0.31 & 0.006 \\
\hline \multicolumn{4}{|c|}{ Sub treatments (Boron levels) } \\
\hline $\mathrm{S}_{1}: 2.5 \mathrm{~kg} \mathrm{ha}^{-1}$ & 1.75 & 7.52 & 0.059 \\
\hline $\mathrm{S}_{2}: 5.0 \mathrm{~kg} \mathrm{ha}^{-1}$ & 2.41 & 8.48 & 0.062 \\
\hline $\mathrm{S}_{3}: 7.5 \mathrm{~kg} \mathrm{ha}^{-1}$ & 2.50 & 8.51 & 0.063 \\
\hline SEm \pm & 0.04 & 0.07 & 0.004 \\
\hline $\mathrm{CD}(\mathrm{P}=0.05)$ & 0.10 & 0.21 & 0.001 \\
\hline \multicolumn{4}{|c|}{ Sub treatment at same level of main treatment } \\
\hline SEm \pm & 0.04 & 0.10 & 0.059 \\
\hline $\mathrm{CD}(\mathrm{P}=0.05)$ & $\mathrm{NS}$ & NS & 0.062 \\
\hline \multicolumn{4}{|c|}{ Main treatment at same/different level of sub treatment } \\
\hline SEm \pm & 0.04 & 0.10 & 0.006 \\
\hline $\mathrm{CD}(\mathrm{P}=0.05)$ & NS & NS & NS \\
\hline
\end{tabular}


Table.2 Leaf area index, crop growth rate and relative growth rate as influenced by boron levels and farmyard manure application

\begin{tabular}{|c|c|c|c|c|c|}
\hline Treatments & $\begin{array}{c}\text { Seed } \\
\text { yield } \\
\left(\mathrm{kg} \mathrm{ha}^{-1}\right)\end{array}$ & $\begin{array}{c}\text { Stover } \\
\text { yield } \\
\left(\mathrm{kg} \mathrm{ha}^{-1}\right)\end{array}$ & $\begin{array}{c}\text { Oil } \\
\text { content } \\
(\%)\end{array}$ & $\begin{array}{c}\text { Protein } \\
\text { content } \\
(\%)\end{array}$ & $\begin{array}{l}\text { Oil yield } \\
\left(\mathrm{kg} \mathrm{ha}^{-1}\right)\end{array}$ \\
\hline \multicolumn{6}{|l|}{ Main treatments } \\
\hline $\mathrm{M}_{1}: \mathrm{RDF}$ & 461 & 938 & 51.0 & 17.7 & 235 \\
\hline $\mathrm{M}_{2}: \mathrm{RDF}+25 \% \mathrm{~N}$ through FYM & 540 & 1087 & 51.1 & 18.0 & 276 \\
\hline SEm \pm & 8.6 & 18.8 & 0.07 & 0.3 & 7.3 \\
\hline $\mathrm{CD}(\mathrm{P}=0.05)$ & 27.8 & 60.1 & NS & NS & 23 \\
\hline \multicolumn{6}{|l|}{ Sub treatments (Boron levels) } \\
\hline $\mathrm{S}_{1}: 2.5 \mathrm{~kg} \mathrm{ha}^{-1}$ & 385 & 904 & 51.00 & 17.9 & 215 \\
\hline $\mathrm{S}_{2}: 5.0 \mathrm{~kg} \mathrm{ha}^{-1}$ & 513 & 1008 & 51.10 & 17.9 & 264 \\
\hline $\mathrm{S}_{3}: 7.5 \mathrm{~kg} \mathrm{ha}^{-1}$ & 521 & 1083 & 51.20 & 17.9 & 269 \\
\hline SEm \pm & 6.1 & 25.0 & 0.03 & 0.11 & 3.0 \\
\hline $\mathrm{CD}(\mathrm{P}=0.05)$ & 19.0 & 77.0 & NS & NS & 9.9 \\
\hline \multicolumn{6}{|c|}{ Sub treatment at same level of main treatment } \\
\hline SEm \pm & 8.7 & 16.9 & 0.4 & 0.1 & 4.4 \\
\hline $\mathrm{CD}(\mathrm{P}=0.05)$ & NS & NS & NS & NS & NS \\
\hline \multicolumn{6}{|c|}{ Main treatment at same/different level of sub treatment } \\
\hline SEm \pm & 11.2 & 27.0 & 0.6 & 0.32 & 5.7 \\
\hline $\mathrm{CD}(\mathrm{P}=0.05)$ & NS & NS & NS & NS & NS \\
\hline
\end{tabular}

\section{Quality parameters}

Results scenario of the quality parameters viz. oil content $(\%)$, oil yield $\left(\mathrm{kg} \mathrm{ha}^{-1}\right)$ and protein content $(\%)$ of sesame crop as influenced by application of boron with or without use of farmyard manure were presented in table 2 .

\section{Oil content $(\%)$}

Sesame crop due to application of RDF along with $25 \% \mathrm{~N}$ through FYM had shown maximum oil content of (51.1 per cent) which was on par with oil content of sesame crop under application of RDF alone (51.0 per cent).

When sub plots were observed the oil content of 51.20 per cent of sesame was higher with $\mathrm{S}_{3}$ (fertilized with $7.5 \mathrm{~kg} \mathrm{~B} \mathrm{ha}^{-1}$ ) and it was on par with $\mathrm{S}_{2}$ i.e. application of $5.0 \mathrm{~kg} \mathrm{~B} \mathrm{ha}{ }^{-1}$ (51.10 per cent). The oil content of sesame crop with $\mathrm{S}_{1}$ i.e. $2.5 \mathrm{~kg} \mathrm{~B} \mathrm{ha}^{-1}$ was found to be lower (51.00) compared to rest of the treatments. However, the oil content was found non-significant in main treatments as well as sub treatments. Interaction effect of oil content of sesame crop influenced by main and a sub treatment was found to nonsignificant. Similar results were obtained by Shaker et al., (2011).

\section{Oil yield (kg ha $\left.{ }^{-1}\right)$}

The oil yield of $276 \mathrm{~kg} \mathrm{ha}^{-1}$ was found to be recorded in the sesame crop under application of RDF along with $25 \% \mathrm{~N}$ through FYM compared to oil yield of $235 \mathrm{~kg} \mathrm{ha}^{-1}$ under application of RDF alone.

Among sub plots, the oil yield of $269 \mathrm{~kg} \mathrm{ha}^{-1}$ of sesame was significantly higher with $\mathrm{S}_{3}$ (fertilized with $7.5 \mathrm{~kg} \mathrm{~B} \mathrm{ha}^{-1}$ ) and it is on par with application of $5.0 \mathrm{~kg} \mathrm{~B} \mathrm{ha}^{-1}\left(264 \mathrm{~kg} \mathrm{ha}^{-1}\right)$. 
The oil yield of sesame crop with $2.5 \mathrm{~kg} \mathrm{~B} \mathrm{ha}^{-1}$ was found to be lower $215 \mathrm{~kg} \mathrm{ha}^{-1}$ compared to rest of the treatments. Interaction effect of oil yield of sesame crop influenced by main and sub treatments were found to be nonsignificant.

Application of RDF $+25 \% \mathrm{~N}$ though FYM gained the highest seed yields and high oil content resulting in higher oil yields. Similar results were recorded by Amery et al., (2011). The treatment fertilized with $7.5 \mathrm{~kg} \mathrm{~B} \mathrm{ha}{ }^{-1}$ recorded significantly higher oil yield might be due to its role in improving fertility and high number of capsules plant ${ }^{-1}$ and number of seeds capsule ${ }^{-1}$ ultimately seed yield of sesame crop. Results were corroborating with Shaker et al., (2011).

\section{Protein content $(\%)$}

Data pertaining to protein content $(\%)$ of sesame crop as influenced by application of boron. The protein content of 18.02 per cent was found to be recorded in the sesame crop under application of RDF along with $25 \% \mathrm{~N}$ through FYM compared to protein content of 18.0 per cent under application of RDF alone.

Among sub plots, the protein content of 17.7 per cent of sesame was significantly higher with $\mathrm{S}_{3}$ (fertilized with $7.5 \mathrm{~kg} \mathrm{~B} \mathrm{ha}^{-1}$ ), $\mathrm{S}_{2}$ i.e. application of $5 \mathrm{~kg} \mathrm{~B} \mathrm{ha}{ }^{-1}$ (17.7 per cent) when compared to application of boron @ 2.5 $\mathrm{kg} \mathrm{ha}^{-1}$ the treatments. However, the protein content of sesame was found to be nonsignificant in both main and sub plot treatments. Interaction effect of protein content of sesame crop influenced by main and sub treatments were found to be nonsignificant. Similar results were recorded by (Dugger, 1983).

From the above experiment, it can be concluded that application of RDF (40-60-40 $\mathrm{kg}$ NPK $\mathrm{ha}^{-1}$ ) along with 25 per cent $\mathrm{N}$ through FYM for sesame crop was ideal for obtaining higher nutrient uptake, seed yield and stover yield. Among different levels of boron, application of boron $\left(5.0 \mathrm{~kg} \mathrm{ha}^{-1}\right)$ was found ideal for sesame in order to obtain higher nutrient uptake, seed yield and stover yield. However, it was on par with application of $7.5 \mathrm{~kg} \mathrm{~B} \mathrm{ha}^{-1}$.

\section{References}

Alloway, B.J. 2008. Micronutrient deficiencies in global crop production. Springer Science Business Media, BV.

Barik, A.K and Fulmali, J. 2011. Effect of integrated plant nutrient supply through organic and mineral sources on productivity of summer sesame. Journal of Oilseeds Research 28(2): 120122.

Bolanos, L., Lukaszewski, K., Bonilla, I and Blevins, D. 2004. Why boron? Plant Physiology and Biochemistry 42: 907912.

Chatterjee, C and Nautiyal, N. 2000. Developmental aberrations in seed of boron deficient sunflower and recovery. Journal of Plant Nutrition 23(6): 835841.

Dugger, W.M. 1983. Boron in plant metabolism. Encyclopedia of Plant physiology. Inorganic Plant Nutrition. 626- 650.

Gitte, A.N., Patil, S.R and Tike, M.A. 2005. Influence of zinc and boron on biochemical and yield characteristics of sunflower. Indian Journal of Plant Physiology 10: 400- 403.

Jeena, M., Suman, J and Indira, M. 2013. Synergistic influence of sulphur and boron on enhancing the productivity of sesame (Sesamum indicum L) grown in an entisol of Kerala. Journal of Indian Society of Soil Science. 61(2): 122- 127.

Oyinlola, E.Y. 2007. Effect of boron fertilizer on yield and oil content of three sunflower cultivars in the Nigerian 
savanna. Journal of Agronomy. 6(3): 421- 426.

Patil, S.B., Vyakaranahal, B.S., Deshpande, V.K and Shekhargouda, M. 2006. Effect of boron and zinc application on seed yield and quality of sunflower restorer line RHA-857. Karnataka Journal of Agricultural Sciences. 19: 708- 710.

Saeed N, Hussain M and Saleem M 2002. Interactive effect of biological sources and organic amendments on the growth and yield attributes of sunflower (Helianthus annuus L). Pakistan Journal of Biological Sciences. 39(2): 135- 136
Shaker, T and Mohammed, A. 2011. Effect of different levels and timing of boron foliar application on growth, yield and quality of sunflower genotypes (Helianthus annuus L). Mesopotamia Journal of Agriculture. 39(3): 16-26.

Dugger, W.M. 1983. Boron in plant metabolism. Encyclopedia of Plant physiology. Inorganic Plant Nutrition. Springer-Verlag, Berlin. 626- 650.

Tripathy, S and Bastia, D.K. 2012. Irrigation and nutrient management for yield augmentation of summer sesame (Sesamum indicum L). Journal of Crop and Weed. 8(2): 53- 57.

\section{How to cite this article:}

Mamatha, K., G.E.Ch. Vidyasagar, P. Laxminarayana and Padmaja, G. 2017. Effect of Boron Levels and Farmyard Manure on Physiological Growth and Quality of Sesame (Sesamum indicum). Int.J.Curr.Microbiol.App.Sci. 6(8): 2568-2574.

doi: https://doi.org/10.20546/ijcmas.2017.608.304 